\title{
Decentralization of public healthcare services in the Province of Sumatera Utara, Indonesia
}

\author{
Februati Trimurni ${ }^{1}$, Norma Mansor ${ }^{2}$ \\ ${ }^{1}$ Department of Public Administration, Faculty of Social and Political Sciences, University of Sumatera Utara, Indonesia \\ ${ }^{2}$ Department of Administrative Studies and Politics, Faculty of Economics and Administration, University of Malaya, \\ Malaysia
}

\section{Article Info}

Article history:

Received Jun 8, 2020

Revised Aug 27, 2020

Accepted Sep 11, 2020

\section{Keywords:}

Decentralization

Deconcentration

Healthcare

Local autonomy

Provincial

\begin{abstract}
The research examined the effectiveness of decentralization program on the healthcare sector at the provincial level in the context of political and administrative decentralization. It adopted qualitative approach and employed the technique of in-depth interview, observation on documentation. Informants consist of public servants, practitioners, community and relevant stakeholders. The implementation of decentralization does not work that ideal for some reason: the devolution and the decentralization programs are not conducted simultaneously, mutually support and complimentary; the lack of local apparatus capabilities to understand and carry out the principles and the practices of the programs in the field; the limitation of financial sources and support to conduct the programs.
\end{abstract}

This is an open access article under the CC BY-SA license.

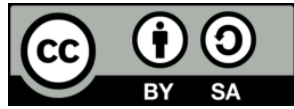

Corresponding Author:

Februati Trimurni,

Department of Public Administration,

Faculty of Social and Political Sciences,

University of Sumatera Utara,

Jl. Prof A. Sofyan No.1 Kampus USU, Medan 20155, Indonesia.

Email: februati@usu.ac.id

\section{INTRODUCTION}

At present, many developing countries including Indonesia practice decentralized systems on governance. This is considered because this system is closely related to the application of democracy, political reform, community participation, empowerment, economic development, accountability and capacity building of human resources [1]. The decentralization system that prevailed in Indonesia began since the "reformation" era in 1998, particularly since the issuance of the Law Number No. 22/1999 concerning on Regional Government. This law itself comes into effect since 2001 and various implementing regulations have been provided to ensure that the policy is effective on the ground. Decentralization is automatically one of the manifestations of good governance and bringing the government closer to the community [2].

The implementation of decentralization system in Indonesia is interesting to study. This because the country adopted an "absolute" centralization system for about 32 years notably under the administration of President Soeharto. According to the World Bank, the implementation of the regional government law after the reformation era has made Indonesia be one of the countries that practice "big bang decentralization" [3]. The Law No 22/1999 has been finally revised twice notably by the Law No. 32/2004 and the latest revision 
by the Law No. 23/2014. Both revisions become the authorities submitted or distributed to the regions less compared to the authorities stipulated in the previous law. The main discussion of this research is about the implementation of decentralization both in the term of politics later namely devolution and term of administrative namely deconcentration in the area of healthcare services [4]. It is seen from the planning stage and implementation phase of the healthcare programs. The health sector in this study is chosen because health care is a basic service and today has become part of the millennium development goals (MDGs) that came as a tool through which governments are struggling to implement and succeed in transforming the lives of their citizenry in all aspects of human endeavor [5].

The main object of the research are the Regional Healthcare Office which is futher more written as Dinas Kesehatan Daerah or Dinkes Daerah, and Community Healthcare Center, later translated as Pusat Kesehatan Masyarakat (Public Health Center) or Puskesmas. In Indonesia, "Puskesmas" roles as primer healthcare, they perform case finding and health service directly to the community [6]. Both are the institutions in the regions owned political authorities as well as policies on the healthcare service governances. Meanwhile, the governor at the provincial level as the representative of the central government in the region owns the administrative authority beside the own political authority in the context of cross-region cases. In the healthcare sector implementation and practices, the governor passes this authority to the Dinkes of Sumatra Utara Province (Dinkes Provinsi). At the central or national level, the political authority and policies on the healthcare sector is the responsibility of the Ministry of Health where in the practical way delivered by the general directors within the ministry. Problem statement of the study is that authority of autonomous region on the public policies and services in the health sector is not necessarily followed by adequate financial and human resource capabilities in implementing policies and carrying out these authorities. One of the deconcentration programs in the health sector is considered as an answer to this problem, but the next question is whether the deconcentration program significantly helps local governments in exercising their authority and responsibilities in the health sector.

\section{LITERATURE REVIEW}

Study on decentralization in Indonesia has been continously carried out in recent years. Hartanti, for example, conducted research on decentralization focussing on administrative authority or deconcentration in the financial management of the education sector [7]. The result of the research found the reduction of administrative authority did not automatically reduce the allocation of funds that were de-concentrated to the regions. The study also found the deconcentration fund does not appropriately allocate based on the region needs. Alfiyanti's research is also related to administrative decentralization, which examines the accountability of the expenditures of $d$ decentralization budgets [8]. The realization of the decentralization budget has reached 91 percent, but it is not properly followed by the evidences of responsibility. The implementation of decentralization activities can be furthermore concluded that are not transparent yet. Meanwhile, Kobandaha analyzed the use of administrative authority possessed by the governor about overseeing the preparation of regional regulations on regional budget [9]. The result of the research is the need for a strict arrangement of the principles of decentralization. This is pivotal, so there is no misuse of the governor's authority against the regent/mayor in the formulation of regional regulations. Although some of the above studies analyze administrative decentralization, all three differ in the scope with this study. Also, the three studies did not discuss the political authority or devolution, which was also the object of this study.

Research on political decentralization in healthcare services has been for instance carried out by the SMERU Research Institute [10]. The study found that the biggest challenge of implementing political decentralization was the unavailability of supporting regulations and directions. The study through the governance and decentralization survey II (GDS II) of Gadjah Mada University also concerns on the same sector in the healthcare services but relating to the availability of facilities and public access to these healthcare facilities [11]. Moreover, the GDS II examines political decentralization in implementing good governance that has not shown significant improvement in the era of regional autonomy in twenty provinces in Indonesia. Whereas, the study of Langran that saw political decentralization from democratic practices found the lack and unfairness of the healthcare budget and community participation that is in fact reflecting the weakness of democracy [12]. Meanwhile, Sun's research in about 64 countries analyzed the relationship between political decentralization and health system performance [13]. Giving bigger decentralization authority to regions can improve the quality of healthcare system performance and the abundant state resources have impacts on the effectiveness of decentralization. In contrast to this study, GDS II research, Langran, and Sun as mentioned above strongly focussed on the discussion on the area of the magnitude of political authority. This study examines the authority of the local governent in the planning stage and implementation phase of the healthcare programs. Actually, Sun also uses 
healthcare programs to see the implementation of decentralization, but the research adopts quantitative research methods while this study uses qualitative methods and health programs vice versa and adopts a case study.

The Zarmaili study also used case studies but the cases adopted were related to administrative services in both healthcare and education sector [14]. The results of the research shown decentralization has not been able to run effectively because the weakness of community participation in the level of planning and supervision of the development of healthcare and education services. Meanwhile, Rajesh and Thomas as well as Exworthy used an institution as a research case [15, 16]. They used the institution of local self-governments as a research case that can facilitate the provision of health services to the community. Whereas Exworthy, Frosini, and Jones used foundation trusts institutions and found a model consisting of three elements, namely the right to make decisions, residual ownership status and market exposure. Public hospital in the practice must own these three elements. The merging of these three elements will produce incentives that encourage the development of entrepreneurial behavior.

Another study by Apreku looked at the administrative, political and fiscal authorities conducted in the healthcare and education sector [17]. The education sector has a greater scope in the context of regional autonomy rather than of healthcare in the terms of finance, service organizations, human resources and governance. Also, the research found the insufficient evidence regarding the impact of decentralization on the performance of the healthcare and education sector, especially seen from the output indicators and outcomes. Furthermore, Kiriaghe's research discussed administrative and political authority together from the perspective of politics [18]. Local governments have the autonomy, but there is little independency and creativeness in utilizing financial resources since the central government remains controls the financial area. Therefore, participation in policy planning remains weak and the level of decentralization is not in the sense of devolution.

This is a multi-level study approach used vertical relations between different levels of government and horizontal relation among institutions those conducting healthcare service in the field. Therefore, it can analyze the role of each government institution or organization in using its authority and also looked the relations among institutions at the sub-district level where the Puskesmas domiciles. Sciortino's research obviously also uses a multi-level stage perspective but focussed more in the perspective of anthropology [19].

The main theories applied in this study are Smith's decentralization theory [20], the decentralization theory of Cheema and Rondinelli [21] and the theory of decentralization of Rondinelli et al. [22]. These theories are chosen based on several reasons. Firstly, Smith's decentralization theory examines decentralization more than a country's territorial hierarchy. It relates and relevant to the system of government in Indonesia, which consists of central, provincial, district/city and sub-district government. Secondly, Smith's decentralization theory divides decentralization in two forms: political decentralization or devolution and administrative decentralization or deconcentration. These forms are general practices of decentralization and widely understood by the majority of government employees and public servant in Indonesia. Thirdly, the theory of Cheema and Rodinelli and that of Rondinelli et al. widely practice in developing countries particularly in the ex-colonial nation. Indonesia in fact is one of the countries in that category.

Finally, the mixture of the theories where Smith observes more decentralization on political side and Rondinelli on economic perspective are regarded compatible to analyze the implementation and the practice of decentralization in Indonesia. Smith's theory, Cheema and Rondinelli as well as Rondinelli et al. in fact do not see the decentralization of politics and administration as two stand-alone concepts but there is a situation that fills, supports and complements one another in providing public services. This study also wants to examine the mixture of the theoretical perspective and analyze the implementation of both political and administrative decentralization by using healthcare sector and programs as a case study. Starting from the gap of past studies, methodology and theories, this research is expected to find new findings that are more specific, comprehensive and detailed from the perspective of public administration. Since the decentralization practice in Indonesia has been dynamic within two decades, the results of this study hopefully can bring about contributions, especially on organizational and managerial aspects, on the development of decentralization practice in Indonesia.

\section{RESEARCH METHOD}

This study used qualitative methods by adopting a case study and multi-level stages approach [23, 24]. The scopes of this study are the healthcare sector where it is one of the basic needs of the community, which is a mandatory regional affair. The main problem of this research is how the concept of decentralization both politically and administratively carried out in healthcare services in the local area. Four local governments in the province of Sumatera Utara is selected as the samples of the study. It consists of two districts which are the district of Deli Serdang and the district of serdang 
Bedagai and two cities which are the city of Medan and city of Binjai. The study adopts purposive sampling in selecting the area. Two Puskesmas of each area which are selected through purposive sampling represents the actual practice of decentralization in the healthcare sector in the area.

The primary data collection techniques in this studyconsist of interviews where in practice conducted by in-depth interviews, ordinary interviews and phone interviews. Other primary data are collected through questionnaire distribution and field observation. Whereas the collection of secondary data needed to support primary data is carried out through documentation techniques. The informants in this study are those who work with the provincial and district/municipal city offices of the healthcare sector, communities, practitioners and other relevant stakeholders that are determined using purposive and snowball sampling techniques. In order to validate data, this study then uses the triangulation method [25].

\section{RESULTS AND DISCUSSION}

\subsection{Theoretical, normative and practical meaning of healthcare decentralization in indonesia}

The theoretical meaning of decentralization, regulative adoption and empirical practice of decentralization in Indonesia is not entirely in line and consistent. However, the practice of health decentralization in general is still meet with the meaning and categories of decentralization as theoretically conveyed by Smith [20] or Cheema and Rondinelli [21]. Devolution is translated as the full handover of powers and authorities to an autonomous region and makes them the domain of regional government. In this case, the central government institutions in charge of the healthcare sector such as regional offices or Kanwil have been liquidated in accordance with the spirit of regional autonomy. Deconcentration is translated when there is power and authority of the central government in the regional administrative area delegated to the provincial government. Deconcentration in this case is only delegated to the governor or the executive element in the provincial level. Delegation as another form of administrative decentralization in the health sector is also very often practiced. In addition to the delegation of tasks assigned by the central government to the provincial government, delegates also carry out tasks by the central government to the district/city directly. Privatization, as another variation of decentralization, has so far not been practiced in the management of public services in the health sector.

The healthcare sector is in practice a concurrent government affair which means that the affairs are jointly owned by the central government, provincial government and district/city government. Each level of government has the scope of duties and authority according to the corridor of the legislation. Resembling the building of a pyramid, the government at the lowest level has greater authority while the highest government has less authority. In the decentralization framework, most services in the health sector are the responsibility and authority of regional governments. This means that he focuses on the implementation of political decentralization lies in the district/city; the provincial government has only the remaining authority in the political sector. Meanwhile, the implementation of administrative decentralization lies in the provinces in the provinces where the district/city governments are only the beneficiaries of the program.

Political decentralization in the health sector, since it was implemented in the last two decades, has not been properly implemented for various reasons. For certain regions with large regional revenues and high economic potential, devolution program is relatively working well. However, it does not apply to the majority of districts/cities through out the country. For autonomous regions with low income levels, the health sector is still far from budget priorities. Low human resource competency, minimal availability of health workers and equitable distribution of human resources between regions in autonomous regions are other kinds of problems that need to get the attention of all parties. In such cases it is necessary to conduct policy interventions so that the health sector as part of basic services can be well managed [26]. Therefore, the practice of deconcentration and assistance tasks carried out by the central government for autonomous regions is still considered important and relevant to remain present and maintained before autonomous regions both provincial and district/city are truly independent according to the spirit of decentralization.

The practice of deconcentration and delegation (co-administration in its legal terminology) has never been absent since decentralization was launched in the last two decades in Indonesia. The central government primarily carries out a deconcentration program in the health sector in almost all provinces each year. The central government through the ministry of health provides a healthcare menu or main health program and allocates several funds for implementing the designed healthcare menu. Furthermore, the Dinkes Provinsi as the governor's executor in this case outlines and breaks the health menu down into healthcare programs, sub-programs and services which are then carried out in the district by the Dinkes Kabupaten/Kota, Puskesmas and the community. In this case the central government no longer designs the program details in accordance with the menu but is carried out by the provincial government. The practice of deconcentration as well as co-administration in fact provides benefits for each party or local 
and central government. The deconcentration program and the co-administration are totally the indicators of the performance of the central government representation by the ministries or state institutions. The success or failure of government performance is also determined by whether or not the performance of the deconcentration program or this co-administrastion. Likewise with the autonomous region both provincial and district/city. The presence of deconcentration programs or co-administration can support the achievement of their main tasks or also fill health programs that have not been able to be carried out by autonomous regions.

\subsection{Decentralization and the challenge of healthcare services}

The implementation of political and administrative decentralization in the province of Sumatra Utara is basically in line with the theories of decentralization as described above. Both of these concepts are in one continuum line, which means the implementation is carried out simultaneously and sometimes complementary. In the domain of decentralization of politics, both provincial and district/city governments have original authorities in the fields of planning, budgeting, regulation, and implementation of the healthcare sector. Meanwhile, in the domain of administrative decentralization, these institutions are only given the task of carrying out the planned, budgeted, and regulated programs by higher government level which are, in this case, the central and provincial governments.

Political decentralization provides autonomy to the districts/cities (Dinkes Kabupaten/Kota and Puskesmas). This study consists of four districts and eight Puskesmas in Sumatra Utara. It explains the implementation of political decentralization through the planning and implementation of health programs as a case study. The healthcare operational assistance (BOK) as part of the national revenue and expenditure budget (APBN) funds the healthcare programs. The BOK is provided by the central government to local governments to help local governments achieve national targets in the healthcare sector, which are the responsibility of autonomous regions. Funding assistance from the central government is proof that the autonomous region has not been able to finance the health sector itself. It is contrast to the decentralization theories where the autonomous government should allocate and pay their programs, expenditures and needs. However, from the results of study, the implementation of political decentralization in the health sector has not gone as expected.

Decentralization of administration or deconcentration is an important part or another component to implement devolution or decentralization broadly. Administrative decentralization in this context does not stand alone and dichotomious within the same locus of authority and administration, but rather two concepts that must co-exist and synergize with each other. Decentralization can properly function if devolution has been carried out properly as well, which means that devolution as an exclusive authority of local government needs the support of deconcentrated programs. If not, the focus of decentralization holders will be disrupted or cause problems. Furthermore, devolution can be conducted well in the provincial government if there is sustainable and consistance supervision and monitoring through decentralization holders.

Based on the findings above, the implementation of administrative decentralization in the healthcare sector in Sumatra Utara has become very important. This is also regarded the deconcentration programs should be kept in the province for several years to come. It is indeed refers to the a large number of deconcentration programs obtained by the autonomous region, especially related to capacity building programs for increasing technical and soft skills in the health sector. Moreover job autonomy is necessary for healthcare professionals to provide quality service [27]. In other words, administrative decentralization activities in this case can be placed as a bridge to realize autonomous regions that can create their programs and finance them independently.

However, administrative decentralization activities in the healthcare sector in Sumatra Utara up to righ now have not reached a maximum level to provide assistance to political decentralization activities. Some of deconcentrated healthcare programs do not comply with the human resource needs in the region. Deconcentration funds are also limited so that the training, guidance or outreach provided by the Dinkes Provinsi to healthcare or non-healthcare human resources and communities in the regions has not provided optimal benefits. Some training materials and guidance only contain general matters, so that they do not significantly add insight or the ability of human resources in the area.

Combining healthcare programs derived from deconcentration funds and those funds originating from the regional budget (APBD) of Sumatra Utara Province can overcome this problem. Unifying or synergizing these health programs can be done because several central government programs are also programs of the government of the province of Sumatra Utara. But it requires high employee creativity and integrity so that these programs can work together with one another. Formulating and integrated planning on the healthcare program among the provincial and districts/cities within the province is regarded as an alternative.

There are differences in the planning of healthcare programs in the "new order" era which adheres to a centralized system comparing to that of "reform" era. In the "new order" era, all healthcare programs came from and designed by the central government while the regional government only implemented 
programs planned by the central government. At that time the governor, regent and mayor were politically elected by the President from the same political party or crony as the President so that there was no reason for them not to carry out the vision and mission of the President who had appointed them. Meanwhile, in the era of "reform" of the central government in this case, President Joko Widodo had his vision and mission that must be achieved by all regional governments both provincial and district/city governments throughout Indonesia. In the healthcare sector, the President's vision and mission are further elaborated by the Ministry of Health to become a healthcare menu. Different from the "new order" era, in the "reform" era, governors, regents and mayors were elected by the people through direct elections and they have their vision and mission in their administrative area. Each can be distinct because governors, regents and mayors are possible to come from different political parties than the President. However, from the research findings, some central government programs on the area of healthcare are the focus of local government as well.

In addition to quality healthcare programs, high human resource capabilities and skills are pivotal in the era of decentralization. The amount of authority of the government in the region must be followed by the ability and skills of its human resources to use the tasks. It is perceived since decentralization requires district/city to be independent and empowered so that they can undertake their own domestic affairs, such as formulating healthcare policies at the regional level and planning creative and innovative healthcare programs and activities by the needs of local people. However, human resources at the Puskesmas as the main institution in implementing healthcare program in the field have not been able to portray healthcare problems optimally. Creating creative and innovative human resources is not an easy matter considering that the work culture in the government bureaucracy has not changed completely. Apart from that, there has not been much visible support from the Dinkes Kabupaten/Kota, so that it is no wonder that the health programs or activities made by the Puskesmas are still similar to the previous years.

In addition to the low capacity and skills of the human resources, the deployment of employees is also a challenge to the successful implementation of decentralization. Puskesmas in city areas, for example, have medical personnel such as general practitioners and dentists exceeding the needs, while Puskesmas in rural areas lack health workers. One of the causes of this uneven distribution is due to the enormous role of outsiders in the placement and transfer of health workers. Dinkes Kabupaten/Kota, for example, are helpless when individuals from the executive, legislative as well as judicial institutions "ask for help" so that they can transfer them to a certain Puskesmas. Meanwhile, the district/city agency implementers have not fully worked based on work analysis and job descriptions. The decentralization policy authorizes the placement or transfer of the health of Puskesmas as well as medical and non-medical employees to the district/city government.

Beside the challenges, the transfer of the head of Puskesmas is not also based on merit system or strategic planning so that it hurt the overall performance of the Puskesmas. One form of lack of planning on this issue is the replacement of the head of the Puskesmas that is too fast. As is known, the role as head of the Puskesmas is not only related to activities within the Puskesmas but also those outside the Puskesmas. It is perceived because the services provided by the Puskesmas require assistance from other institutions or sectors such as sub-districts, kelurahan/villages, and so on. Therefore, time is needed to adapt to all stakeholders from this Puskesmas. To overcome the various problems faced by the autonomous region in implementing the, it is necessary to have political and environmental support in which the healthcare sector is run. Political support at the local level can consist of legislative, executive, civil society organizations (CSOs) and service providers while environmental support includes the availability of regulations, policies and advocacy from all parties including the non-health sector [28].

\subsection{Health sector funding in the decentralization framework}

In the context of political decentralization, local governments should implement and finance healthcare programs which are their responsibility and authority. Local annual budget or APBD must be the source of financing for healthcare services in the district/city. This logic will run smoothly for regions that have large regional budgets and have sufficient income sources and not having high population densities. The amount of the APBD will then be directly proportional to the number of funds allocated to the health service sector. The 2009 Health Law itself requires an allocation of at least $10 \%$ of the APBD excluding of personnel salary for the health care sector. However, the budget division per service sector, including healthcare services, still requires political will from the regents/mayors of each region. Although healthcare sector services are parts of basic services, the government does not immediately follow up with strict legal norms relating to the minimum percentage of the budget allocation for the health sector. Data from the Province of Sumatera Utara in 2019 describes the total budget for the healthcare sector is only 372.9 billion or only $2.53 \%$ of the annual provincial budget [29].

Based on the data of the Ministry of Finance in 2018, as many as 402 regions have met the allocation mandatory of healthcare expenditures [30]. However, there are still 146 or more than $25 \%$ of the total autonomous regions in Indonesia that has not been able to or have not shown a commitment to fulfill 
the mandatory health sector spending. The number of regions that have not been able to or do not have the political will in allocating compulsory health sector spending has actually occurred since the 2009 Health Law regulations. One reason is the amount of budget allocation for salaries. A total of 131 local governments in Indonesia spend half of the APBD on employee salaries (excluding soldiers) [31]. Even this budget that is not too large in the end does not fully reach the community in the context of building health services. According to Wildmalm, in developing countries, the biggest challenges in health and education development come from corrupt practices committed by officials, politicians, teachers, or health workers [32].

One reason that at least 10 percent of the total APBD does not fulfill for the healthcare sector is due to the small amount of district/city regional original income (PAD). Of the four districts/cities that are the location of this study, Medan has the more prominent PAD in Sumatra Utara as shown in Table 1. The amount of PAD makes Medan one of the areas where Puskesmas employees receive welfare benefits every month. Also, in the decentralization era, there was a significant influence between the number of PAD and the number of programs implemented in the Puskesmas and district/city healthcare offices.

\begin{tabular}{lccc} 
Table 1. Original income of four district/cities in Sumatera Utara \\
\cline { 2 - 4 } District/municipal city & \multicolumn{3}{c}{ Regional original income (in Billion } \\
& 2016 & Rupiahs) & 2017 \\
& 672.2 & 662.6 & $1,000.9$ \\
\hline Deli Serdang & 89.2 & 102.4 & 219.1 \\
Serdang Bedagai & 1,827 & $1,973.7$ & $2,112.7$ \\
Medan & 88.7 & 98.2 & 136 \\
Binjai & $4,541.6$ & $5,01.4$ & 3,499 \\
Sumatra Utara &
\end{tabular}

Source: Central Bureau of Statistics, Sumatra Utara, 2017-2019

The majority of autonomous regions in Indonesia, including Sumatra Utara, remain dependent on the Regional Budget in financing healthcare programs. The APBD consists of revenues from PAD, revenue sharing funds (DBH), general allocation funds (DAU), and special allocation funds (DAK). Preferably, the financing of healthcare services and also the financing of development programs that responsiblity through their PAD. However, the vast majority of regions in Indonesia, including in Sumatra Utara, still depend on $\mathrm{DBH}, \mathrm{DAU}$, and DAK in financing healthcare programs. It is in line with the fact that the PAD in each autonomous region has not had a significant amount. Meanwhile, the potential tax objects in the district/city such as income tax, value-added tax, export/import tax, and so on are still the object of central government tax. Such a distribution system has failed to achieve the goal of equity between rich and poor regions [33].

From the explanation above, the relationship between political authority and administrative authority is close, especially in countries that have autonomous regions that are not yet fully independent due to the limited financial and human resource capacity. Administrative decentralization possessed by the Governor as a representative of the central government can be used to cover up the limitations that local governments have as autonomous regions. Also, the administrative authority can be used by the governor to reduce the gap between autonomous regions in a province which is his responsibility so that they can prosper its people as the goal of implementing political decentralization.

However, administrative affairs ideally can be considered incrementally to be left to the affairs of autonomous regions and carried out buy them independently [34]. Therefore, it needs a new formula for the gradual reduction of the authority of the central government in the regions as an autonomous region. It is inseparable from the opinion of Ostwald et al., that decentralization in Indonesia is a transitional process to accommodate the demands of reform in 1998 [35]. So it's implementation is not an effort to create an efficient government, but is rather the method chosen to overcome critical with fast that happened at that time. In addition, it needs the new formula for the authority of the central government in the regions, reform of the financial balance system between the central government and local governments. Through this reform, the regional government finances are getting bigger, so they are better prepared to implement devolution policies.

\section{CONCLUSION}

The implementation of decentralization in both political decentralization or devolution and administrative decentralization or deconcentration in the healthcare sector in Sumatra Utara, cannot be said to have been running optimally. There are three main factors which are the causes, which are related to the object of the healthcare programs, human resources, and finance. The relationship between political decentralization and administrative decentralization in the healthcare sector in the province of Sumatra Utara

Int. J. Public Health Sci, Vol. 9, No. 4, December 2020: $364-372$ 
is important and very close. Programs and financing for healthcare sector administration can help implement a political decentralization program in the healthcare sector. The relationship between the two decentralizations type is also explained to be always directly proportional in the sense of the word that the bigger the financing of administrative decentralization programs, the better the implementation of devolution in the health sector. However, the bigger the funding and administrative decentralization programs carried out by the central government, the smaller the independence of the regions.

Recommendations of the study are placed at least on four fields which are: (1) the necessary to synergize the programs of devolution and the deconcentration on the ground; (2) political and environmental support such as legislative, executive, civil society organizations (CSOs), regulations and policy, along with advocacy from the non-health sectors; (3) the empowerment and improvement of local capabilities to implement the healthcare sector as well as; (4) the urgency to reform and improve local fiscal system.

\section{ACKNOWLEDGEMENTS}

Authors thank all local government apparatus, informants as well as colleagues for allocating their valuable times to support data for this research.

\section{REFERENCES}

[1] P. Smoke, "Decentralisation in Africa: Goals, Dimensions, Myths and Challenges," Public Administration and Development, vol. 23, no.1, pp. 7-16, 2003.

[2] S. Ladi., "Good Governance And Public Administration Reform," Athens Greece: ICBSS Xenophon Paper, 2008.

[3] B. Hoffman and K. Kaiser, "The Making of the Big Bang and its Aftermath: A Political Economy Perspective" in Reforming Intergovernmental Fiscal Relations and the Rebuilding of Indonesia," Cheltenha: Edward Elgar Publishing, 2004.

[4] G. S. Cheema and D.A. Rondinelli, "Decentralization and Development: Policy Implementation in Developing Countries,” Beverly Hills, London, New Delhi: Sage Publications, 1983.

[5] P.G. Sow and V. Vinekar, "Effect of Public Librairies in the Attainment of Health Millennium Development Goals in Senegal," International Journal of Public Health Science (IJPHS), vol. 1, no. 1, pp. 11-18, July 2012.

[6] Nurul I.K and Sulistyawati, "Acceptance of Health Information System for Public Health Centre in North Borneo, Indonesia," International Journal of Public Health Science (IJPHS), vol. 7, no. 3, pp. 168-174, September 2018.

[7] E. Hartanti, "Ministry of National Education Deconcentration Fund Allocation and the Compliance with Government Regulation No. 38 of 2007,” Jakarta: Universitas Indonesia, 2010.

[8] R. Alfiyanti, "Evaluation of Deconcentrated Accountability at the Department of Energy and Mineral Resources," Jakarta: Universitas Indonesia, 2010.

[9] M. Kobandaha, "Implementation of Deconcentration Tasks by the Governor: Study of Drafting on Regional Budgets in Bolaang Mongodow Regency,” Jurnal Hukum Unsrat, vol. 1, no. pp. 55-63, Oct. 2013.

[10] S. Usman et al., "Implementation of Decentralization and Regional Autonomy, Cases of Three Districts in North Sulawesi and Gorontalo," Jakarta: Lembaga Penelitian SMERU, 2001.

[11] W. Widyanti, et al., "The State of Local Governance and Public Services in Decentralized Indonesia in 2006: Findings From the Governance and Decentralization Survey 2 (GDS2)," Jakarta: SMERU Research Institute Jakarta, 2008.

[12] I.V. Langran, "Decentralization, Democratization, and Health: The Philippine Experiment," Journal of Asian and African Studies, vol. 46, vol. 4, pp. 361-374, Jun. 2011.

[13] F. Sun, "An Exploratory Study of the Relationship Between Decentralization and Health System Performance," Birmingham: University of Alabama, 2003.

[14] Zarmaili, "Decentralization and Devolution of Power: A CASE Study in the Jambi Region of Jambi, Indonesia," Jabatan Pengajian Pentadbiran dan Politik Fakulti Ekonomi dan Pentadbiran, Kuala Lumpur: Universiti Malaya, 2010.

[15] Rajesh, K. \& Thomas, M. B, "Decentralization and Interventions in the Health Sector," Journal of Health Management, vol. 14, no. 4, pp. 417-433, Jan. 2013.

[16] M. Exworthy, et al., "Are NHS Foundation Trusts Able and Willing to Exercise Autonomy? 'You Can Take a Horse to Water,' Journal of Health Services Research \& Policy, vol. 16, no. 4, pp. 232-237, Sept. 2011.

[17] S.S. Apreku, "Does Decentralization Improve Public Service Delivery? Issues and Policy Implications for Uganda," Thesis (M.D.E), Uganda: Dalhousie University, 2003.

[18] U.M. Kiriaghe, "The Impact of Decentralization on Health Service Delivery in Western Uganda" Uganda: ProQuest Information and Learning Company Database, 2006.

[19] R. Sciortino, "Puskesmas Nurses in between Treatment and Care" Yogyakarta: Gadjah Mada University Press, 2007.

[20] B.C. Smith, "Decentralization: The Territorial Dimension of the State" UK: George Allen and Unwin Ltd, 1985.

[21] G. S. Cheema and D.A. Rondinelli, "Decentralization and Development: Policy Implementation in Developing Countries," Beverly Hills, London, New Delhi: Sage Publications, 1983.

[22] D.A. Rondinelli, et al., "Decentralization in Developing Countries," A Review of Recent Experience, USA: World Bank, 1984.

[23] R.K. Yin, "Case Study Research. Design and Methods," California: Sage Publications, 2014. 
[24] S. Van der Geest, et al., "Primary Health Care in a Multi-level Perspective: Towards a Research Agenda," Social Science \& Medicine, vol. 30, no. 9, pp. 1025-1034, 1990.

[25] J.W. Creswell and C.N. Poth, "Qualitative Inquiry and Research Design: Choosing Among Five Approaches" London: Sage Publications, 2017.

[26] P. Bhasin, "An Assessment of Health-Economic Burden of Obesity Trends with Population-Based Preventive Strategies in a Developed Economy," International Journal of Public Health Science (IJPHS), vol. 6, no. 2, pp. 124-133, June 2017.

[27] Sumathi G. N. "Human Resource Practices in Public Healthcare Sector: A Perceptual Study among Healthcare Professionals" International Journal of Public Health Science (IJPHS), vol. 6, no. 1, pp. 51-56, March 2017.

[28] Perigrinus S., et al. "Sustainability Capacity of HIV/AIDS Programmes in Yogyakarta, Indonesia" International Journal of Public Health Science (IJPHS), vol. 6, no. 4, pp. 314-323, December 2017.

[29] Government of Sumatera Utara Province, "Report of Government Performance of Healthcare Office 2019", Dinkes Provinsi Sumatera Utara, Medan, 2019.

[30] Ministry of Finance, "Regional Expenditures and Improvement of Public Services: Case Study for Education and Health," Direktorat Jenderal Perimbangan Keuangan, Kementerian Kesehatan, 2018.

[31] Detik, "Sri Mulyani: There are 131 Regions that are Half the Regional Budget Exhausted for Civil Servant Salary" Wednesday, 10 May 2017. [Online]. Available: Detiknews, https://finance.detik.com/

[32] S. Widmalm, "Decentralization, Corruption and Social Capital: From India to the West New Delhi," India: Sage Publications, 2008.

[33] L. Schmit, "Indonesia Law and Society" in "Decentralization and Legal Reform in Indonesia: The Pendulum Effect (The Second Edition), T. Lindsey, Ed.," Australia: The Federation Press, 2008.

[34] D.A. Rondinelli, et al, "Decentralization in Developing Countries," A Review of Recent Experience, USA: World Bank, 1984.

[35] K. Ostwald, et al., "Indonesia's Decentralization Experiment: Motivations, Successes and Unintended Consequences," Southeast Asian Economies (JSEAE), vol. 33, no. 2, pp. 139-156, Aug. 2016. 